\title{
Citrus Stubborn Severity Is Associated with Spiroplasma citri Titer But Not with Bacterial Genotype
}

\author{
Alexandre F. S. Mello, Oklahoma State University, Department of Entomology and Plant Pathology, Stillwater \\ 74078; Raymond K. Yokomi, United States Department of Agriculture-Agricultural Research Service (USDA- \\ ARS), Parlier, CA 93648; Ulrich Melcher, Oklahoma State University, Biochemistry and Molecular Biology, Still- \\ water; Jianchi C. Chen, USDA-ARS, Parlier; and Jacqueline Fletcher, Oklahoma State University, Department of \\ Entomology and Plant Pathology, Stillwater
}

\begin{abstract}
Mello, A. F. S., Yokomi, R. K., Melcher, U., Chen, J. C., and Fletcher, J. 2010. Citrus stubborn severity is associated with Spiroplasma citri titer but not with bacterial genotype. Plant Dis. 94:75-82.

The impact of citrus stubborn disease, caused by Spiroplasma citri, on citrus production is associated with the symptom severity of infected trees but its association with bacterial levels and virulence are unknown. Fifty-eight $S$. citri isolates were cultivated from severely and mildly symptomatic trees and randomly amplified polymorphic DNA and short-sequence repeat fingerprinting differentiated four major $S$. citri genotypes among these isolates. Each genotype was present in both mildly and severely symptomatic trees, suggesting that readily detectable genetic differences in the $S$. citri populations did not account for differences in disease severity. No variation in the size of amplicons of the pathogenicity-related fructose operon was observed in isolates from trees having varying degrees of symptom expression. Quantitative polymerase chain reaction demonstrated that spiroplasma titer is over 6,000 times higher in fruit from severely symptomatic than from mildly symptomatic trees. The genotypic similarities among $S$. citri isolates from severely and mildly symptomatic trees, and the consistently higher bacterial titer in the former than in the latter, suggests that titer but not genotype is, at least in part, responsible for the greater symptom severity in some of the $S$. citri-affected trees in the orchard evaluated.
\end{abstract}

Citrus stubborn disease (CSD) has been reported in California for over 50 years, and Spiroplasma citri was confirmed as its causal agent in 1972 and 1973 (14,35). S. citri, a phloem-limited mollicute, is transmitted in a propagative manner by several species of leafhoppers or by graft propagation using infected budwood (22,31). During infection and colonization, $S$. citri utilizes carbohydrates and sterols from its plant host $(1,10)$, thus competing with the host for these nutrients and causing the depletion of some sugars and hormones, and the accumulation of others, in plant cells. The resulting imbalance affects the metabolism of the plant, causing stunting and leaf mottling (1). In addition, S. citriinfected citrus trees produce smaller and fewer fruit than do healthy trees, and have

Corresponding author: J. Fletcher

E-mail: jacqueline.fletcher@okstate.edu

Accession numbers: GQ 152123, GQ 152124, GQ152125, GQ152126, and GQ152127.

Accepted for publication 3 September 2009.

doi:10.1094/PDIS-94-1-0075

This article is in the public domain and not copyrightable. It may be freely reprinted with customary crediting of the source. The American Phytopathological Society, 2010. off-season blooming, multiple axillary buds, and shortened internodes (8).

CSD symptom expression is influenced by temperature, and one report indicated that leaf mottling and stunting were obvious under warm conditions $\left(30\right.$ to $\left.35^{\circ} \mathrm{C}\right) 5$ to 8 weeks after spiroplasma inoculation $(3,33)$.

The impact of $S$. citri on citrus production seems to be related to symptom severity, because severely symptomatic citrus trees had lower yield and produced fewer and smaller fruit than did mildly symptomatic trees (25). The reason for variation in symptom severity under field conditions is not fully understood but could be associated with bacterial titer within the plant or variations in bacterial virulence $(7,8)$.

The very small genome of $S$. citri facilitates deletion or acquisition of genetic components, thus enhancing the microbe's fitness (24). Continuous graft transmission of $S$. citri from periwinkle to periwinkle resulted in a chromosomal inversion and genomic deletions in $S$. citri BR3-3X that were associated with loss of transmissibility by the beet leafhopper Circulifer tenellus $(42,44)$. Repeated subculturing in artificial medium also altered $S$. citri transmissibility (42).

The $S$. citri genome has evolved over a relatively short period of time (24). Genomic changes could result in the emergence of $S$. citri strains having enhanced aggressiveness, enabling more efficient use of carbohydrates or sterols, causing greater nutritional imbalance in the host and, thereby, increasing symptom severity in citrus. Alternatively, an earlier inoculation or higher initial inoculum titer could lead to broader distribution and multiplication of the spiroplasma in the trees, thereby increasing disease severity.

Variations in CSD symptom severity within a single orchard led us to compare the genetic diversity among $S$. citri isolates from severely symptomatic trees with those from mildly symptomatic trees. Randomly amplified polymorphic DNA polymerase chain reaction (RAPD-PCR) and short-sequence repeat (SSR) markers and primers designed to amplify parts of the pathogenicity-related fructose operon $(16,17)$ were used. RAPD-PCR, using lowstringency conditions (23) and random primers having short nucleotide sequences, efficiently discriminates genetic diversity among some plant-pathogenic bacteria, including S. citri isolates (27). Although the reproducibility of RAPD fingerprints can be influenced by the template and $\mathrm{MgCl}_{2}$ concentration (15), the specific thermocycler used $(30,40)$, and the intensity of amplicons used to score the fingerprint (37), RAPD fingerprints can be very reproducible under well-established laboratory conditions (28).

SSRs are single- or multinucleotide sequences, repeated in the genomes of prokaryotic and eukaryotic cells, arising from slipped-strand mispairing, inadequate mismatch repair, or mutagenesis (41). The function of SSRs is not well established but is assumed to be related to protein encoding sequences (41). SSRs are frequently used as molecular markers and are useful in assessing the genetic structure of populations of plant-pathogenic bacteria (11).

To elucidate whether the difference in CSD symptom severity in infected trees is related to specific $S$. citri isolates or to spiroplasma titer in trees as measured in the fruit, quantification of the pathogen in fruit from severely and mildly CSD symptomatic trees was performed by quantitative PCR (q-PCR).

\section{MATERIALS AND METHODS}

Bacterial isolates and cultivation. $S$. citri isolates were obtained from a plot 
within a commercial orchard in northeastern Kern County, CA, that contained approximately 1,800 sweet orange (Citrus sinensis (L.) Osb.) trees of cv. Thompson Improved Navel, grafted onto Carrizo citrange $(C$. sinensis $\mathrm{Osb} \times \mathbf{P}$ Poncirus trifoliata L. Raf.) rootstock. Trees were approximately 20 years old. An initial set of 15 CSD-symptomatic trees was selected. Seven trees presented mild symptoms (a few branches showing abnormally short internodes or leaf mottling) and eight trees presented severe symptoms (tree stunting, leaf mottling and short internodes on all branches, off-season blooms, large fruit size variability and, misshapen fruit; Fig. 1). Because of its higher suitability for bacterial cultivation from fruit compared with other citrus tissues (26), the receptacle tissue between the peduncle and the central axis or axial bundle (columella) of the fruit was used as the source for bacterial cultivation. Ten fruit were harvested at random from each of $15 \mathrm{CSD}$-affected trees (7 mildly and 8 severely symptomatic) in August 2007. Receptacles from the 150 fruit were individually processed for spiroplasma cultivation in LD8 broth
$(5,21)$. Cultures were evaluated daily for turbidity and spiroplasma growth was confirmed by dark-field microscopy (39) using an Olympus $\mathrm{BH}-2$ microscope $(\times 1,200$; Olympus Optical Co., Tokyo). Aliquots from cultures that yielded $S$. citri cells were transferred to LD8-agar plates and, later, single colonies were transferred from the plates to fresh LD8 broth. The 5- to 7day-old cultures reached a titer of approximately $10^{8}$ cells $/ \mathrm{ml}$, based on direct cell counts using dark-field microscopy. At least one fruit from each of the 15 citrus trees yielded a positive $S$. citri culture. Seventy-four $S$. citri cultures were obtained from the 150 fruit, and 58 of these were frozen at $-20^{\circ} \mathrm{C}$ and used for DNA extraction.

DNA extraction. $S$. citri cells from the 58 cultures frozen above were harvested by centrifugation, pellets were resuspended in cetyltrimethylammonium bromide (CTAB) buffer, and DNA extraction was accomplished via standard procedures (12). The DNA pellets were dissolved in water and quantified with a spectrophotometer (ND-1000; Nanodrop, Wilmington, DE . The DNA solution was diluted to
$4 \mathrm{ng} / \mu \mathrm{l}$, stored at $-20^{\circ} \mathrm{C}$, and used in RAPD, SSR, and fructose operon-PCR evaluations.

RAPD-PCR. Eleven 10-oligonucleotide primers, previously reported to discriminate $S$. citri isolates (OPA-09, OPA-13, OPA-15, OPA-18, OPN-11, OPC-03, OPC-13, OPH-08, OPB-20, OPQ-06, and OPAW-05; Operon Technologies, Alameda, CA), were used in RAPD amplifications (28). PCR reaction mixtures and conditions were as previously reported (28). PCR reactions without DNA template were used as negative controls. DNA from $S$. citri strains BR3-3X, isolated from horseradish (Armoracia rusticana P.G. Gaertn., B. Mey. \& Scherb) (13); C17, isolated from carrot (Daucus carota L.) (28); and ASP-1, a strain originally from citrus (38); and from $S$. phoeniceum (provided by R. Davis) and $S$. kunkelii CR2 (9), were used as internal controls. A PTC200 thermocycler (MJ Research, Inc., Ramsey, MN) was used for all experiments and reactions were performed twice. PCR products were electrophoresed in $1.5 \%$ Tris-acetate-EDTA (TAE)-agarose (36) at $100 \mathrm{~V} / \mathrm{cm}$. Gels were stained with

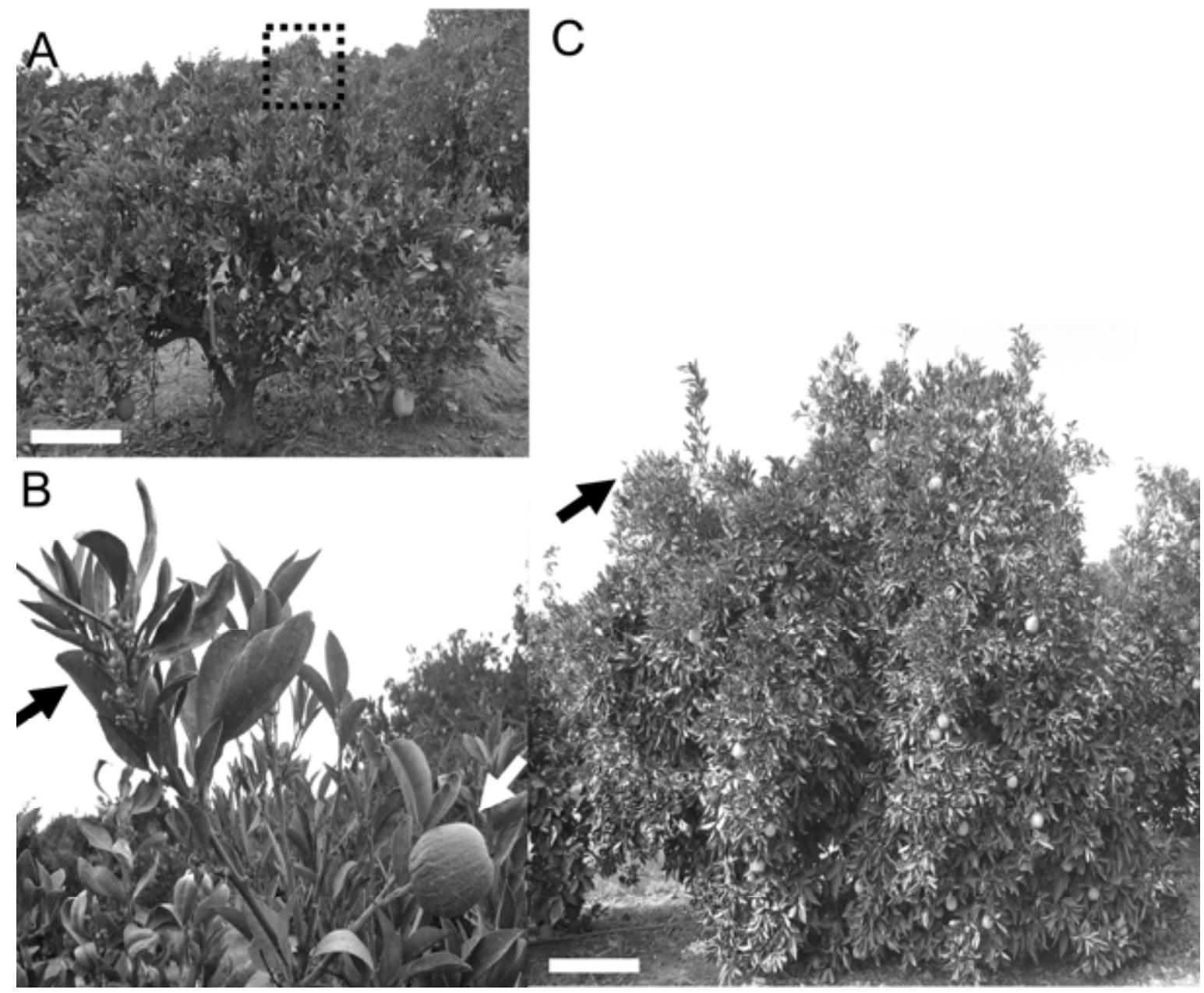

Fig. 1. Sweet orange trees (Citrus sinensis (L.) Osb.) cv. Thompson Improved Navel, grafted on carrizo citrange $($ C. sinensis Osb. $\times$ Poncirus trifoliata L. Raf.) rootstock) presenting citrus stubborn disease symptoms of varying degrees of severity A, Severely symptomatic tree showing stunting, shortened internodes within the canopy, and misshapen fruit of different sizes. B, Close-up of a branch from A (boxed region) showing shortened internodes, acorn-shaped fruit (white arrow), and off-season blooming (black arrow). C, Mildly symptomatic tree showing mostly normal tree development but shortened internodes in some parts of the tree canopy (black arrow). No off-season blooming or acorn-shaped fruit were noticed. Bars represent $0.5 \mathrm{~m}$. 
ethidium bromide and visualized using an AlphaImager and Alphaease FC software (Alpha Innotech Corporation, San Leandro, CA). Amplicon sizes were estimated by comparison to a 1-kb-plus DNA Ladder (Invitrogen, Carlsbad, CA).

SSR amplification. Thirty-seven contiguous chromosomal sequence blocks (contigs AM285302 to AM285339) from the $S$. citri strain GII-3 genome were retrieved from the National Center for Biotechnology Information (NCBI). Because Plectovirus sequences constitute a large portion of the S. citri genome and usually are associated with genetic variability, sequences of four Plectovirus spp. from $S$. citri SpV1-R8A2, SpV1-C74, SVTS2, and SVGII-3 (accession numbers NC_001365, NC_003793, NC_001270, and AJ96242, respectively) were also obtained from NCBI. Sequences were evaluated by the program Tandem Repeat Finder (2). Four contigs containing SSRs having at least five copies and a cutoff of $80 \%$ of sequence match within the repeats were used for primer design. Primers were selected 40 to 268 nucleotides upstream or 14 to 195 nucleotides downstream of the SSR to avoid excessive terminal thymines, which can lead to nonspecific amplification (18) (Table 1). Reaction mixtures were the same as described for RAPDs and included DNA obtained from the $58 \mathrm{~S}$. citri cultures. PCR conditions included initial denaturation at $95^{\circ} \mathrm{C}(3 \mathrm{~min})$; followed by $30 \mathrm{cy}-$ cles of $95^{\circ} \mathrm{C}(15 \mathrm{~s}), 50^{\circ} \mathrm{C}(30 \mathrm{~s})$, and $72^{\circ} \mathrm{C}$ (1 min); and a final cycle of $72^{\circ} \mathrm{C}(5 \mathrm{~min})$. PCR reactions without DNA template were used as negative controls. PCR products were electrophoresed in $3.0 \%$ TAEagarose at $50 \mathrm{~V} / \mathrm{cm}$. Gel staining and visualization was done by methods described for the RAPD reactions. Five amplicons obtained from SSR reactions were sequenced using standard methods in an automated 3730 DNA analyzer (Applied Biosystems, Foster City, CA), and sequences were aligned by CLUSTAL (19) with sequences retrieved from NCBI.

RAPD and SSR patterns were assessed visually. The presence or absence of bands in each isolate was transformed into binary data (presence $=1$, absence $=0$ ) and these data were analyzed by principal component analysis (SAS/PRINCOMP, SAS software 9.1; SAS Institute, Cary, NC) to assess whether $S$. citri isolates from mildly or severely symptomatic trees clustered differently (20).

Fructose operon. Five primer pairs were designed from the sequences of three genes (fruR, fruA, and fruK) and the translation initiation factor (infB) of the fructose operon, NCBI accession number AF202665, using Primer 3 software (34) (Table 2). PCR mixtures were the same as used in the RAPD and SSR analyses and PCR conditions were the same as used in the SSR evaluation. Reactions without DNA template were used as negative controls. PCR products were electrophoresed in $1.5 \%$ TAE-agarose at $100 \mathrm{~V} / \mathrm{cm}$. Gel staining and visualization was done by methods described for the RAPD reactions.

q-PCR. $S$. citri isolate 160 , which was obtained in 2006 (28) from the same orchard sampled in this study, was subcultured in LD8 broth. Cells were diluted 10fold in phosphate-buffered saline (PBS) amended with $10 \%$ sucrose (PBS-sucrose) and plated onto $0.8 \%$ LD8 agar. Plates were incubated at $30^{\circ} \mathrm{C}$ and the number of CFU was assessed 11 days after subculture.

To establish an internal standard allowing correlation of spiroplasma titer
$(\mathrm{CFU} / \mathrm{ml})$ and the cycle threshold $(\mathrm{Ct})$ values from the PCR, the same $S$. citri suspension used for the serial dilution was used for DNA extraction. Using a protocol adapted from Oliveira et al. (32), $1 \mathrm{ml}$ of $S$. citri culture $\left(3.40 \times 10^{8}\right.$ cells $)$ was harvested at $10,000 \times g$ for $10 \mathrm{~min}$, the supernatant was discarded, and the pellet mixed with $0.6 \mathrm{~g}$ of finely minced $S$. citri-free citrus fruit central axis (columella). Then, $1 \mathrm{ml}$ of $2.5 \times$ CTAB buffer was added and the mixture was homogenized in a MiniBeadBeater-96 (Bio-Spec Product, Bartlesville, OK) for $3 \mathrm{~min}$ using $0.75-\mathrm{cm}$ ceramic spheres (MP Biomedicals, Solon, $\mathrm{OH})$. DNA extraction was accomplished via standard procedures (12), and the DNA pellet was dissolved in $50 \mu \mathrm{l}$ of water and quantified using a spectrophotometer (ND1000; Nanodrop) and analyzed in $1.5 \%$ TAE agarose gels. The DNA solution was diluted to $50 \mathrm{ng} / \mu \mathrm{l}$ and stored at $-20^{\circ} \mathrm{C}$.

Primers used in q-PCR were designed with homology to the sequence of the single copy gene of the membranelocated spiralin protein (4) SP1 219f (5' AAGCAGTGCAAGGAGTTGTAAAAA $\left.3^{\prime}\right)$ and SP1 298r (5' TGATGTACCTTT GTTGTCTTGATAAACA 3') (R. Yokomi, personal communication). A real-time PCR assay was developed using the DNAbinding fluorophore SYBR Green I in PCR mixtures previously reported (45) using $10^{2}$ to $10^{-5} \mathrm{ng}$ of the template mixture of $S$.

Table 2. Primers used to assess the presence of insertions or deletions in the fructose operon genes of isolates of Spiroplasma citri cultivated from sweet orange trees with mild or severe symptoms of citrus stubborn disease

\begin{tabular}{lllcc}
\hline Genes & Primers $^{\mathbf{z}}$ & \multicolumn{1}{c}{ Sequences $\left(\mathbf{5}^{\prime} \rightarrow \mathbf{3}^{\prime}\right)$} & $\begin{array}{c}\text { Primer binding sites on } \\
\text { fructose operon }\end{array}$ & $\begin{array}{c}\text { Amplicon } \\
\text { size (bp) }\end{array}$ \\
\hline infB & InfB Fwd & CAGCTGACGATGGGGTAATG & $64-83$ & 943 \\
& InfB Rev & TCCTTCTGCTGCTGCAACTA & $988-1,007$ & $\ldots$ \\
fruR & fruR Fwd & TTGCAATTATCACCAACAACA & $1,480-1,500$ & 602 \\
& fruR Rev & AATTTCAACTTCCGAACGAGA & $2,062-2,082$ & $\ldots$ \\
fruA & fruA-1 Fwd & CTACGCCATCTCAAGGAGGA & $2,431-2,450$ & 693 \\
& fruA-1 Rev & ATCATGCCGCAACATCACTA & $3,104-3,124$ & $\ldots$ \\
& fruA-2 Fwd & CAGGCTGAGCAAATACATGG & $3,280-3,299$ & 793 \\
\multirow{4}{*}{$f r u K$} & fruA-2 Rev & TGCTACACCAATTGAAGCAC & $4,054-4,073$ & $\ldots$ \\
& fruK Fwd & GGTGATTGGTGGAAAAGGAA & $4,353-4,372$ & 676 \\
& fruK Rev & CAGCAACCATTGAATCACCA & $5,013-5,029$ & $\ldots$ \\
\hline
\end{tabular}

${ }^{\mathrm{z}} \mathrm{Fwd}$ and Rev $=$ forward and reverse primer, respectively.

Table 1. Primers used to assess the number of short-sequence repeats (SSRs) of isolates of Spiroplasma citri cultivated from sweet orange trees with mild or severe symptoms of citrus stubborn disease

\begin{tabular}{|c|c|c|c|c|c|c|}
\hline Primers & Sequences & Location & Contig $^{x}$ & $\begin{array}{c}\text { Period } \\
\text { size }^{y}\end{array}$ & $\begin{array}{c}\text { Copy } \\
\text { number }\end{array}$ & $\begin{array}{l}\text { Matched sequence } \\
\text { repeats }(\%)^{\mathrm{z}}\end{array}$ \\
\hline SSR $02 \mathrm{~F}$ & TCATGATATGCGATATGTTCAGA & $124,021-124,043$ & AM285302 & 3 & 15 & 90 \\
\hline SSR $02 \mathrm{R}$ & CCATATATTGTAAAAGGCAATGACA & $124,151-124,176$ & & & & \\
\hline SSR $06 \mathrm{~F}$ & GGTGCTAAATTACAAAAGAACAATTAGACC & $16,024-16,053$ & AM285306 & 3 & 11 & 94 \\
\hline SSR $06 \mathrm{R}$ & AGCCAATTTATTATTTATAATTGTAATAACATC & $16,228-16,260$ & & & & \\
\hline SSR 20A F & CGCTTAATTTCTCGTAAAATAGTACTACGATG & $5,721-5,759$ & AM285320 & 3 & 8.7 & 100 \\
\hline SSR 20A R & GGTATATAAATGTTATGTATAGTCATTTGAGTTTTATG & $5,881-5,908$ & & $\ldots$ & & \\
\hline SSR 20B F & TACTATCATTGGTTTTTTAATTTGAGGTGA & $16,131-16,160$ & AM285320 & 6 & 23.3 & 100 \\
\hline SSR 20B R & GCATTTACAGGATTCCATGATTAATAAG & $16,342-16,369$ & $\ldots$ & $\ldots$ & $\ldots$ & $\ldots$ \\
\hline
\end{tabular}

\footnotetext{
${ }^{x}$ GenBank accessions from which primers were designed.

${ }^{y}$ Number of nucleotides that constitute each SSR.

${ }^{\mathrm{z}}$ Percentage of nucleotide repeats within the contigs retrieved from the GenBank that matched with the theoretical nucleotide repeats suggested by the program Tandem Repeat Finder (2).
} 
citri and citrus previously described. Reactions were performed on a iQ5 Real-Time PCR System (Bio-Rad, Hercules, CA) and the amplification consisted of an initial denaturation at $95^{\circ} \mathrm{C}$ for $3 \mathrm{~min}$, followed by 37 cycles at $95^{\circ} \mathrm{C}$ for $20 \mathrm{~s}$ and $55^{\circ} \mathrm{C}$ for $45 \mathrm{~s}$ (annealing and extension). Control samples in each run included distilled water, DNA extracts from fruit columellas of $S$. citri-free citrus plants, and DNA extracted from $S$. citri cultures. To confirm the size and the sequence specificity of the real-time amplicons, a melting curve was generated by increasing the temperature from 55 to $95^{\circ} \mathrm{C}$ in increments of $0.5^{\circ} \mathrm{C} / 10$ s. Real-time PCR products were separated in 3\% agarose and amplicons were visualized by staining with ethidium bromide.

From the initial $15 \mathrm{~S}$. citri-infected citrus trees, 6 representatives (3 with mild symptoms and 3 with severe symptoms) were used in the evaluation. Fruit were harvested from specific locations within the tree: two canopy aspects (one facing east and the other facing west) and three canopy tiers (top third, middle third, and base third), for a total of 6 samples per tier and 18 samples per tree. When present, fruit with "acorn" or lopsided shape (common symptoms of $S$. citri infection in fruit) were preferentially selected. Fruit receptacles (central axes) were excised and minced. A quantity of $0.6 \mathrm{~g}$ of this tissue was mixed with $1 \mathrm{ml}$ of $2.5 \times$ CTAB buffer and homogenized in a MiniBeadBeater-96 (Bio-Spec Product) for 3 min with ceramic spheres. DNA extraction was accomplished via standard procedures (12), and DNA pellets were dissolved in $50 \mu \mathrm{l}$ of water and quantified using a spectrophotometer (ND-1000; Nanodrop). The DNA solution was diluted to $50 \mathrm{ng} / \mu \mathrm{l}$ and $100 \mathrm{ng}$ of template was used in q-PCR reactions as described above for the development of a standard curve.

Sample titer (CFU equivalent per milligram of citrus columella tissue) was estimated by interpolation of the Cts obtained from the field samples on a standard curve developed with the $\mathrm{Ct}$ and the $\log _{10}$ of the initial quantity of DNA template. q-PCR reactions were performed twice and the Cts obtained in both evaluations were averaged.

Statistical analyses were performed using PC SAS (version 9.1; SAS Institute). Analysis of variance was used to compare factor levels. The number of spiroplasma cells was transformed with a natural logarithm function to address homogeneity of variance. The three factors of interest were symptom status (mildly or severely symptomatic), aspect (east or west), and canopy tier (top, middle, or base). These factors were arranged in a split-plot arrangement with status as the main-unit factor and aspect and tier as split-unit factors. The simple effect of each factor was assessed with a SLICE option in an LSMEANS statement. A 0.05 level of significance was used for all comparisons.

\section{RESULTS}

RAPD and SSR variation. All 11 RAPD primers yielded differential amplification patterns among the three spiroplasma species evaluated (S. citri, S. phoenicium, and S. kunkelii) (data not shown), and 3 (OPA-09, OPN-11, and OPQ-06) differentiated $S$. citri isolates cultivated from mildly or severely symptomatic trees as well as differentiating $S$. citri (Fig. 2, lanes 1-58 and 60-62) from $S$. phoenicium and S. kunkelii (Fig. 2, lanes 63 and 64, respectively). The five differential RAPD amplicons obtained with the three different primers ranged from 1.65 to $0.85 \mathrm{kbp}$ in size. Patterns that revealed the greatest diversity among isolates are presented in Figure 2. Two main genetic patterns, con-

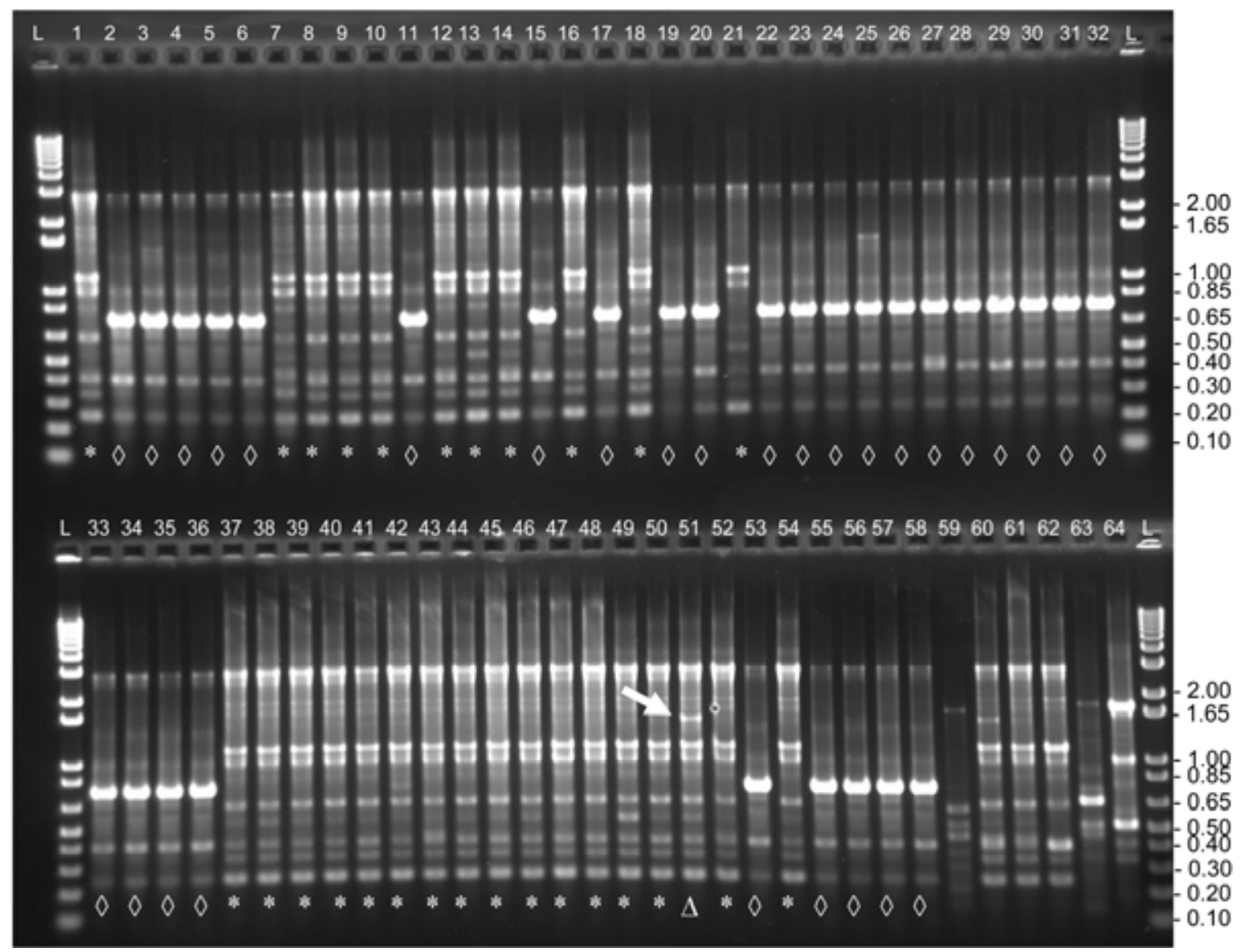

Fig. 2. Randomly amplified polymorphic DNA fingerprint generated with primer OPN-11. DNA was extracted from 58 Spiroplasma citri isolates selected by single-cell cloning from fruit harvested from citrus trees having mild or severe symptoms of citrus stubborn disease (CSD). Lanes 1-19, S. citri isolates from CSD mildly symptomatic trees. Lanes $20-58, S$. citri isolates from CSD severely symptomatic trees. Lane 59, no DNA template. Lanes 60-62, S. citri strains BR3-3X, C17, and ASP-1, respectively. Lanes 63 and 64, S. phoenicium and S. kunkelii, respectively. L, DNA ladder 1-kb plus; fragment sizes (kb) listed on right. The two major $S$. citri genotypes are identified by $*$ and $\diamond$. One isolate having an amplicon different from the other two genotypes (lane 51 ) is identified by the symbol $\Delta$ and the differential amplicon is indicated by an arrow. 
sistent with the three primers used, were identified. Pattern 1 can be seen in lanes 1 , $7-10,12-14$, and others marked by an asterisk at the bottom of the gel lane and pattern 2 can be seen in lanes $2-6,11,15$, 17 , and others marked by a diamond at the bottom of the gel lane (Fig. 2). No genetic pattern was consistently associated with S. citri isolates cultured from severely or mildly symptomatic trees, and some trees contained both genotypes. Pattern 2 in lane 6 and pattern 1 in lanes 7 and 8 were obtained from a mildly symptomatic tree, and pattern 2 in lane 20 and pattern 1 in lane 21 from a severely symptomatic tree (Fig. 2).

From the 42 contigs evaluated, 28 had SSRs identified by Tandem Repeats Finder software (2). The number of repeats per contig ranged from 1 to 33 but very few repeats were $100 \%$ identical (data not shown). The scarcity of perfect repeats within the contigs led us to design additional primers homologous to sequences having percentage matches as low as $90 \%$ (Table 1). Four SSR primers were designed from three different contigs with an expected amplicon size ranging from 155 to $239 \mathrm{bp}$, with a minimum of three nucleotide repeats and at least 8.7 copies (Table 1). None of the four Plectovirus sequences evaluated had repeats that matched the criteria used in this study.

No differences in amplicon sizes were observed between 58 DNA samples from mildly or severely symptomatic trees (data not presented). Representative amplicons were obtained with primer pairs SSR 06, 20A, and 20B from trees with mild (Fig. $3 \mathrm{~A}$, lanes 1,3 , and 5 ) or severe symptoms (Fig. 3A, lanes 2, 4, and 6). Of the five SSR primers, only SSR 02 yielded polymorphic amplicons among $S$. citri isolates but neither amplicon was specifically associated with $S$. citri from trees with mild (Fig. 3B, lanes 1 and 2) or severe symptoms (Fig. 3B, lanes 3 and 4). Sequencing of amplicons obtained with primers SSR
02, 06, 20A, and 20B showed that the numbers of copies of SSRs were different from those of the original sequences retrieved from NCBI. Amplicons obtained with SSR 02 had 10 or 13 TAA repeats whereas the original sequence from $S$. citri strain G II-3 had 15 repeats. Amplicons obtained from primers $20 \mathrm{~A}$ and $20 \mathrm{~B}$ had 3.7 and 2.3 repeats while the reference copy numbers from NCBI were 8.7 and 23.3, respectively. Amplicons obtained from primer SSR 06 had 5 AAT repeats while the original sequence had 11. The five sequences obtained were submitted to NCBI and received accession numbers GQ 152123 to GQ152127.

Using DNA from $58 \mathrm{~S}$. citri isolates obtained from mildly and severely CSD- symptomatic trees, five RAPD and two SSR differential amplicons were obtained. Using these differential amplicons as input for principal component analysis, five clusters were obtained (Fig. 4). All clusters, except that at coordinates 2,0 (that contains a single isolate), included $S$. citri isolates from both mild and severely symptomatic trees. The four clusters that contained isolates from both symptom types were so tightly structured that the star symbols representing isolates from CSD mildly symptomatic trees overlapped with the open circles that represent isolates from CSD severely symptomatic trees (Fig. 4).

Fructose operon. The five primers homologous to the three genes of the fructose

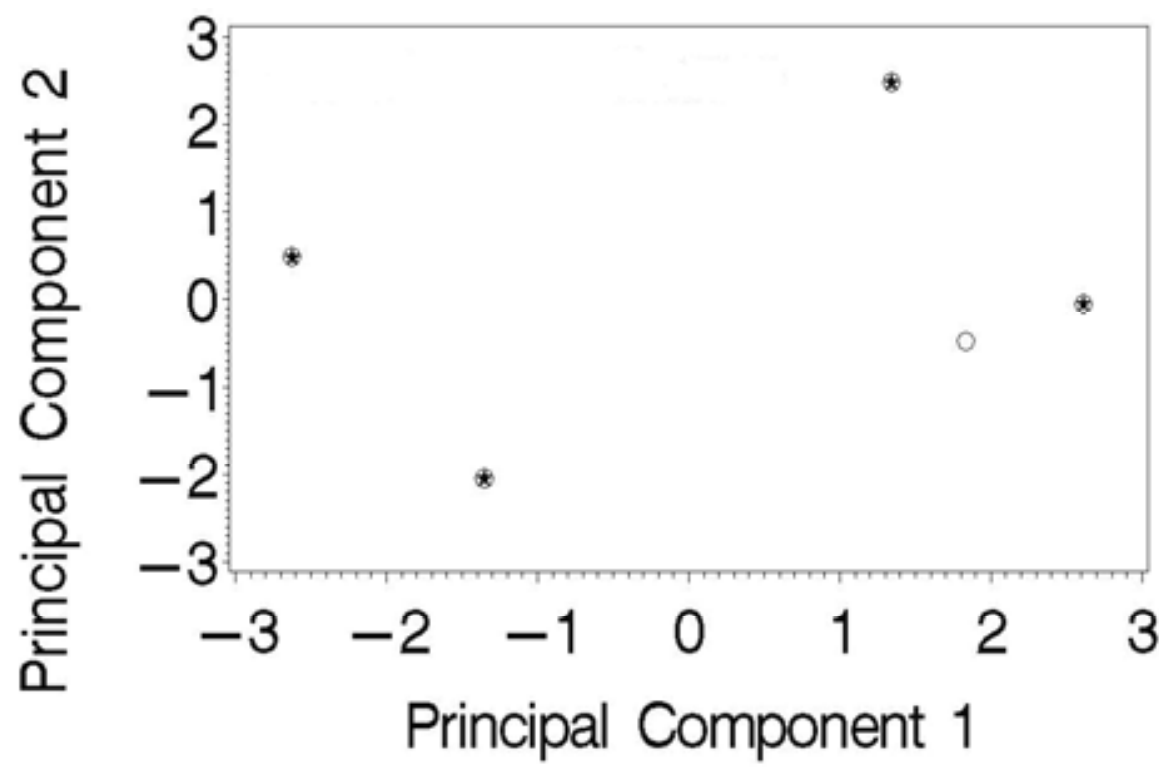

Fig. 4. Clustering of Spiroplasma citri isolates cultivated from trees with mild or severe symptoms of citrus stubborn disease based on principal component analysis using, as input, the differential characters obtained from randomly amplified polymorphic DNA and short-sequence repeat analysis. Stars represent $S$. citri isolates cultivated from mildly symptomatic trees, open circles represent isolates cultivated from severely symptomatic trees, and circles enclosing stars represent clusters of $S$. citri isolates cultivated from both mildly and severely symptomatic trees. All clusters except that on coordinates 2,0 included $S$. citri isolates from both mildly and severely symptomatic trees.
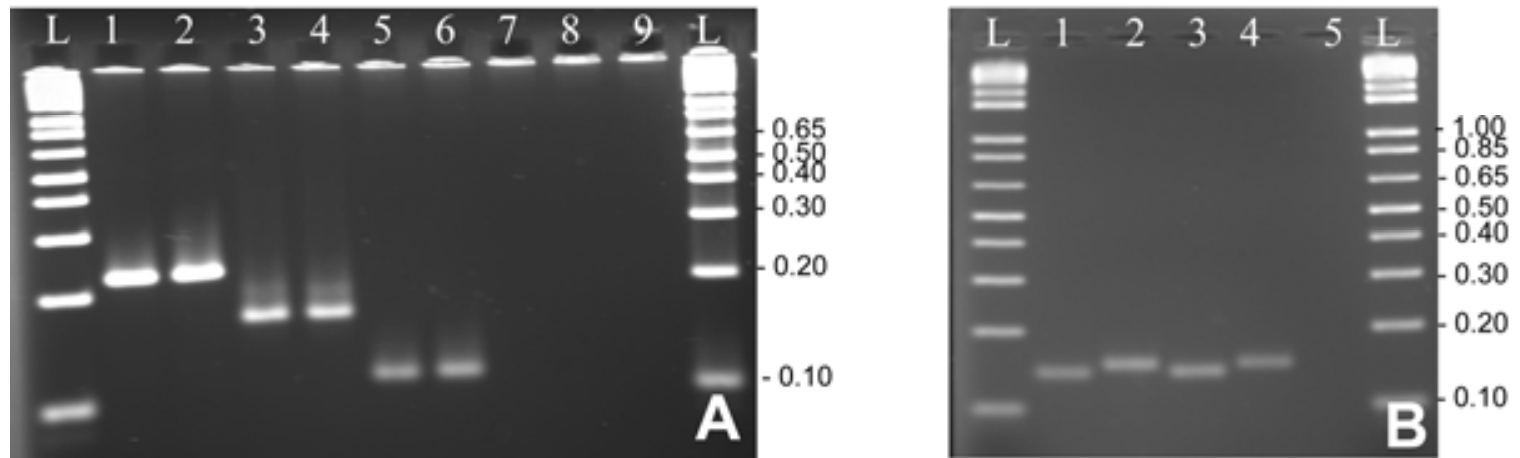

Fig. 3. Amplicons derived with primers designed to amplify sequence repeats from Spiroplasma citri genomes of isolates obtained from citrus trees having mild or severe symptoms of citrus stubborn disease. Lane L, DNA ladder 1-kb plus, fragment sizes (kb) on right. A, Lanes 1, 3, and 5 show amplicons obtained with DNA of $S$. citri isolates from mildly symptomatic trees using short-sequence repeat (SSR) primers 06, 20A, and 20B, respectively. Lanes 2, 4, and 6 show amplicons obtained with DNA of $S$. citri isolates cultivated from severely symptomatic trees using primers SSR 06, 20 A, and 20B, respectively. Lanes 7-9 are control reactions with no template DNA using primers SSR 06, 20 A, and 20B, respectively. B, Differential amplicon sizes yielded by polymerase chain reactions with primer SSR 02. Lanes 1 and 2, amplicons obtained with DNA of $S$. citri isolates from mildly symptomatic trees. Lanes 3 and 4 , amplicons obtained with DNA of $S$. citri isolates from severely symptomatic trees. Lane 5, control reaction with no template. Lane L, DNA ladder 1-kb plus, fragment sizes $(\mathrm{kb})$ on right. 
operon (fruR, fruA, and fruK) and the translation initiation factor (infB) yielded amplicons of the expected size, with no amplification from the control reactions lacking DNA template (data not presented). No difference in amplicon size, which would suggest occurrence of major insertion or deletion events, was observed (data not presented).

Quantification of S. citri by q-PCR. Primers homologous to the single-copy spiralin gene were highly specific, with no amplification from controls. No formation of primer dimers occurred, as shown by the single peak in the melting curve of all reactions, which yielded single bands on 3\% agarose gels (data not shown). Quantified amounts of $S$. citri DNA corresponding to $4.3 \times 10^{0}$ to $4.3 \times 10^{6} \mathrm{CFU}$ of $S$. citri were used in the establishment of the standard curve (Fig. 5). Increasing the amount of DNA template in q-PCR reactions yielded lower $\mathrm{Ct}$ values (Fig. 5). q-PCR reliably amplified the template DNA when initial copy numbers ranged from 4,300 to $4,300,000$, yielding $\mathrm{Ct}$ values of 32.30 and 20.47, respectively. The corresponding linear regression was $y=-4.0333 x+$ 44.367, with a regression coefficient of 0.98 .

S. citri titers in severely and mildly extrapolating the mean $\mathrm{Ct}$ value for the test samples into the standard curve previously developed (Fig. 5). The average S. citri CSD-symptomatic trees were calculated by

titer in severely symptomatic trees $(7.1 \times$ $10^{3}$ CFU equivalents per milligram of columella tissue) was statistically different $(P<0.05)$ from that in mildly symptomatic trees (1.15 CFU equivalents per milligram of columella tissue). No statistical differences were associated with tree canopy tier (base, middle, or top) for $S$. citri titers in either mild or severely affected trees (data not shown). The only tree aspect (east or west) statistically different was in the comparison of severely symptomatic CSD trees in the upper tier (Table 3).

\section{DISCUSSION}

Variation in CSD symptom severity in affected citrus trees was reported in 1969 , when the disease was still attributed to a virus-like organism (6). The factors underlying these different symptom levels could involve more aggressive pathogen strains $(6,8)$ or higher spiroplasma titer in severely symptomatic plants (7). The association of disease severity with yield and fruit quality (25) led us to study further the determinants of CSD severity in one sweet orange orchard in California.

Genetic diversity in bacteria can be assessed by a variety of assays, including examining variability in specific restriction sites or repetitive elements within complete or partial genome sequences or by differences in the amplicons produced by random primers (RAPD; 23). RAPD and

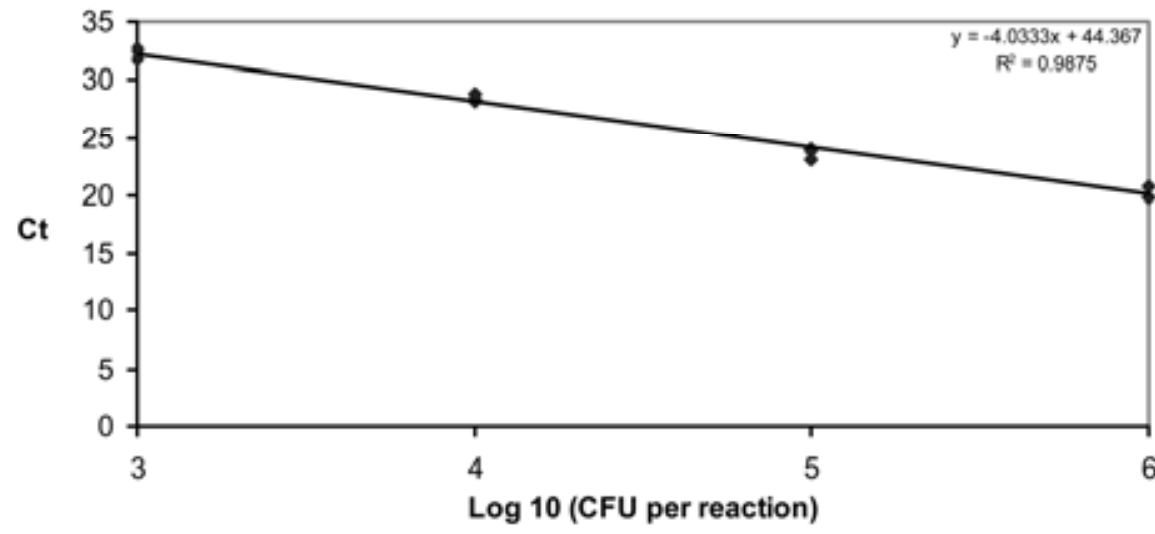

Fig. 5. Real-time polymerase chain reaction standard curve obtained from 10-fold dilutions of DNA extracted from an Spiroplasma citri culture of known titer. The cycle threshold value $(\mathrm{Ct})$ is plotted against the $\log _{10}$ of the number of $S$. citri cell equivalents (CFU) calculated to yield DNA concentrations which give the indicated $\mathrm{Ct}$ values. The derived linear regression equation is indicated in the upper right.
SSR primers used in the present study were suitable for differentiating $S$. citri from other members of spiroplasma serogroup I (S. kunkelii and $S$. phoeniceum) and also for differentiating among $S$. citri isolates found within the same tree.

RAPDs and SSRs identified four major distinguishable $S$. citri populations in the 15 sweet orange trees sampled. Only one isolate, obtained from a severely symptomatic tree, yielded an amplicon that was different from those of the four major genotypes. Both mildly and severely symptomatic trees contained all four variants of S. citri, and some trees had mixed populations of the four, but no relationship between tree symptom status and $S$. citri genotype was identified. Significant $S$. citri genetic variability apparently has existed in California for a long period of time (28). Previous work also using RAPD markers showed that $S$. citri isolates obtained from neighboring grapefruit trees in the Coachella Valley, CA, yielded as many differential amplicons as did those from trees in orchards that were separated by a greater distance. The presence of more than one spiroplasma genotype per tree also was previously reported (28).

The $S$. citri genome, one of the largest among Mollicutes, is characterized by a low guanine-cytosine content. In addition to its circular chromosome, S. citri also harbors plasmids and virus genomes, which likely serve as sources of genetic information that influence the behavior of S. citri $(24,43)$. Little is known about the mechanisms related to $S$. citri pathogenicity and plant symptom expression (17). Mutagenesis, using random insertions of the transposon Tn4001, has shown a relationship between the fructose operon and both $S$. citri pathogenicity and delayed host symptom expression (17). The fructose operon comprises three genes (fruR, fruA, and $f r u K$ ) that normally transcribe two messenger RNAs. Mutations within the fructose operon resulted in a lack of transcription and prevented fructose utilization (17), which reduced the aggressiveness of mutant $S$. citri, resulting in plants having milder symptoms than those inoculated with the wild-type spiroplasma $(16,17)$. The $58 \mathrm{~S}$. citri isolates utilized in this study yielded amplicons of the expected size from fructose-operon genes, suggesting that insertions or deletions in

Table 3. Means and standard errors of Spiroplasma citri CFU equivalents detected in sweet orange trees presenting mild or severe symptoms of citrus stubborn disease in two different aspects (east or west) and three different canopy tiers (base, middle, or top) ${ }^{\mathrm{x}}$

\begin{tabular}{|c|c|c|c|c|c|c|}
\hline \multirow[b]{2}{*}{ Symptom } & \multicolumn{3}{|c|}{ East $^{\mathrm{y}}$} & \multicolumn{3}{|c|}{ West $^{\mathbf{y}}$} \\
\hline & Base $^{\mathrm{z}}$ & Middle $^{\mathrm{z}}$ & Top $^{\mathrm{z}}$ & Base $^{\mathrm{z}}$ & Middle $^{\mathrm{z}}$ & Top $^{\mathrm{z}}$ \\
\hline Mild & $0.9 \pm 0.9 \mathrm{Ba}$ & $1.1 \pm 1 \mathrm{Ba}$ & $2.3 \pm 2.3 \mathrm{Ba}$ & $2.6 \pm 2 \mathrm{Ba}$ & $0.0 \pm 0 \mathrm{Ba}$ & $0.0 \pm 0 \mathrm{Ba}$ \\
\hline Severe & $2,573 \pm 714 \mathrm{Aa}$ & $3,960 \pm 2,433 \mathrm{Aa}$ & $2,971 \pm 1,385 \mathrm{Ab}$ & $17,033 \pm 8,488 \mathrm{Aa}$ & $12,407 \pm 7,311 \mathrm{Aa}$ & $3,983 \pm 1,366 \mathrm{Aa}$ \\
\hline
\end{tabular}

${ }^{\mathrm{x}}$ Different capital letters within a column indicate a statistical difference at $(P<0.05)$ and different lowercase letters within a row indicate a statistical difference at $(P<0.05)$ between the same tier of the different aspects.

${ }^{y}$ Data from fruit columellas from 54 fruit from east and west aspects each from three mildly and three severely symptomatic trees.

${ }^{z}$ Data from fruit columellas from 36 fruit from each canopy tier (base, middle, and top) from three mildly and three severely symptomatic trees. 
this operon were unlikely occurrences in the spiroplasma population studied.

The use of q-PCR to quantify bacterial populations in citrus vascular tissues has been described (32). In our study, the $S$. citri titer in severely symptomatic trees was over 6,000 times higher than that in mildly symptomatic trees, independent of tree canopy tier or aspect. Recent studies of $S$. citri cultivated from fruit receptacles showed that cultures from mildly symptomatic trees took longer to achieve log phase than those cultivated from severely symptomatic trees, suggesting a higher titer of the bacterium in the latter (29). In the same study, q-PCR with primers homologous to the multicopy P58 gene also showed that $S$. citri was more widely distributed within the canopy of severely symptomatic trees than in mildly symptomatic trees (29). Our current findings confirm those from these earlier studies.

In the sweet orange orchard evaluated in the present study, the severity of CSD symptoms was associated with bacterial titer but not with pathogen genotype. Different genetic approaches identified four main genotypes of $S$. citri genotype classes in this orchard, and all four were present in both mildly and severely symptomatic trees. The findings elucidate a historic question about the probable cause of differences in CSD symptom expression levels. The reasons for the higher spiroplasma population and broader distribution in severely symptomatic trees remains unclear but our data are consistent with explanations of earlier infection or higher numbers of infection sites.

\section{ACKNOWLEDGMENTS}

This study was funded by United States Department of Agriculture-Agricultural Research Service (USDA-ARS) project number 530222000-009-00 and by the Oklahoma Agricultural Experiment Station Hatch Project 2052. We thank E. Civerolo (USDA-ARS, Parlier, CA) and C. Bender and C. Garzón (Oklahoma State University) for reviewing the manuscript; M. Payton and C. Goad for the statistical analysis; L. Whitworth (Recombinant DNA/Protein Resource Facility of Oklahoma State University) for assistance in amplicon sequencing; and R. A. Grantham and J. Dominiak Olson (Oklahoma State University) for the use of their real-time PCR system.

\section{LITERATURE CITED}

1. Andre, A., Maucourt, M., Moing, A., Rolin, D., and Renaudin, J. 2005. Sugar import and phytopathogenicity of Spiroplasma citri: glucose and fructose play distinct roles. Mol. Plant-Microbe Interact. 18:33-42.

2. Benson, G. 1999. Tandem repeats finder: a program to analyze DNA sequences. Nucleic Acids Res. 27:573-580.

3. Bové, J. M., Calavan, E. C., Capoor, S. P., Cortez, R. E., and Schwarz, R. E. 1974. Influence of temperature on symptoms of California stubborn, South Africa greening, India citrus decline and Philippines leaf mottling diseases. Pages 12-15 in: 6th Conf. Int. Org. Citrus Virol. L. G. Weathers and M. Cohen, eds. Riverside, CA.

4. Bové, J. M., Foissac, X., and Saillard, C. 1993. Spiralins. Subcell. Biochem. 20:203-223.
5. Bové, J. M., Whitcomb, R. F., and McCoy, R. E. 1983. Culture techniques for spiroplasmas from plants. Pages 225-234 in: Methods in Mycoplasmology. J. G. Tully and S. Razin, eds. Academic Press, Inc., New York.

6. Calavan, E. C. 1969. Investigations of stubborn disease in California: indexing, effects on growth and production, and evidence for virus strains. Pages 1403-1412 in: Proc. First Int. Citrus Symp. Univ. Calif. Riverside.

7. Calavan, E. C., and Bové, J. M. 1989. Ecology of Spiroplasma citri. Pages 425-485 in: The Mycoplasmas. R. F. Whitcomb and J. G. Tully, eds. Academic Press, Inc., New York.

8. Calavan, E. C., and Oldfield, G. N. 1979. Symptomatology of spiroplasmal plant diseases. Pages 37-64 in: The Mycoplasmas. R. F. Whitcomb and J. G. Tully, eds. Academic Press Inc., New York.

9. Castro, V., Rivera, C., Isard, S. A., Gamez, R., Fletcher, J., and Irwin, M. E. 1992. The influence of weather and microclimate on Dalbulus maidis (Homoptera: Cicadellidae) flight activity and the incidence of diseases within maize and bean monocultures and bicultures in tropical America. Ann. Appl. Biol. 121:469-482.

10. Chang, C. J. 1998. Pathogenicity of aster yellows phytoplasma and Spiroplasma citri on periwinkle. Phytopathology 88:1347-1350.

11. Coletta-Filho, H. D., and Machado, M. A. 2002. Evaluation of the genetic structure of Xylella fastidiosa populations from different Citrus sinensis varieties. Appl. Environ. Microbiol. 68:3731-3736.

12. Doyle, J. J., and Doyle, J. L. 1987. A rapid DNA isolation procedure for small quantities of fresh leaf tissue. Phytochem. Bull. 19:11-15.

13. Fletcher, J., Schultz, G. A., Davis, R. E., Eastman, C. E., and Goodman, R. M. 1981. Brittle root disease of horseradish: evidence for an etiological role of Spiroplasma citri. Phytopathology 71:1073-1080.

14. Fudl-Allah, A. E. S. A., Calavan, E. C., and Igwegbe, E. C. K. A. 1972. Culture of a mycoplasmalike organism associated with stubborn disease of citrus. Phytopathology 62:729731.

15. Gao, Z., Jackson, K. M., and Leslie, D. E. 1996. Pitfalls in the use of random amplified polymorphic DNA (RAPD) for fingerprinting of gram negative organisms. Pathology 28:173-177.

16. Gaurivaud, P., Danet, J.-L., Laigret, F., Garnier, M., and Bové, J. M. 2000. Fructose utilization and phytopathogenicity of Spiroplasma citri. Mol. Plant-Microbe Interact. 13:11451155.

17. Gaurivaud, P., Laigret, F., Garnier, M., and Bové, J. M. 2000. Fructose utilization and pathogenicity of Spiroplasma citri characterization of the fructose operon. Gene 252:61-69.

18. Hartl, D. L., and Jones, E. W. 2005. Genetics-Analysis of Genes and Genomes. Jones and Bartlett Publishers, Sudbury, MA.

19. Higgins, D. G., Bleasby, A. J., and Fuchs, R. 1992. CLUSTAL V: improved software for multiple sequence alignment. Comput. Appl. Biosci. 8:189-191.

20. Johnson, D. E. 1998. Principal component analysis. Pages 93-146 in: Applied Multivariate Methods for Data Analysis. Duxbury Press, Belmont, CA.

21. Lee, I. M., and Davis, R. E. 1983. New media for rapid growth of Spiroplasma citri and corn stunt spiroplasma. Phytopathology 74:84-89.

22. Liu, H.-Y., Gumpf, D. J., Oldfield, G. N., and Calavan, E. C. 1983. The relationship of Spiroplasma citri and Circulifer tenellus. Phytopathology 73:585-590.

23. Louws, F. J., Rademaker, J. L. W., and Bruijn, F. J. 1999. The three Ds of PCR-based genomic analysis of phytobacteria: diversity, detection, and disease diagnosis. Annu. Rev. Phytopathol. 37:81-125.
24. Melcher, U., and Fletcher, J. 1999. Genetic variation in Spiroplasma citri. Eur. J. Plant Pathol. 105:519-533.

25. Mello, A. F. S., Fletcher, J., and Yokomi, R. K 2007. Spiroplasma citri infection affects yield and fruit quality in commercial citrus grove in California. (Abstr.) Phytopathology 97:S74.

26. Mello, A. F. S., Yokomi, R. K., and Fletcher, J. Assessment of citrus stubborn disease incidence in citrus. In: Proc. 17th Conf. Int. Organ. Citrus Virol. In press.

27. Mello, A. F. S., Yokomi, R. K., Melcher, U Chen, J., and Fletcher, J. 2006. Assessment of genetic diversity in Spiroplasma citri by RAPD, rep-PCR and bacteriophage primers. (Abstr.) Phytopathology 96:S77.

28. Mello, A. F. S., Yokomi, R. K., Melcher, U., Chen, J. C., Wayadande, A. C., and Fletcher, J. 2008. Genetic diversity of Spiroplasma citri strains from different regions, hosts, and isolation dates. Phytopathology 98:960-968.

29. Mello, A. F. S., Yokomi, R. K., Payton, M., and Fletcher, J. 2008. Citrus stubborn symptom severity and Spiroplasma citri location within the tree canopy. (Abstr.) Phytopathology 98:S104.

30. Meunier, J.-R., and Grimont, P. A. D. 1993. Factors affecting reproducibility of random amplified polymorphic DNA fingerprint. Res. Microbiol. 144:373-379.

31. Oldfield, G. N., Kaloostian, G. H., Pierce, H D., Calavan, E. C., Granett, A. L., Blue, R. L., Rana, G. L., and Gumpf, D. J. 1977. Transmission of Spiroplasma citri from citrus to citrus by Scaphytopius nitridus. Phytopathology 67:763-765.

32. Oliveira, A. C., Vallim, M. A., Semighini, C. P., Araújo, W. L., Goldman, G. H., and Machado, M. A. 2002. Quantification of $X y$ lella fastidiosa from citrus trees by real-time polymerase chain reaction assay. Phytopathology 92:1048-1054.

33. Olson, E. O., and Rogers, B. 1969. Effects of temperature on expression and transmission of stubborn disease of citrus. Plant Dis. Rep. 53:45-49.

34. Rozen, S., and Skaletsky, H. J. 2000. Primer3 on the WWW for general users and for biologist programmers. Pages 365-386 in: Bioinformatics Methods and Protocols: Methods in Molecular Biology. S. Krawetz and S. Misener, eds. Humana Press, Totowa, NJ.

35. Saglio, P., L'hospital, M., Lafleche, D., Dupont, G., Bové, J. M., Tully, J. G., and Freundt, E. A. 1973. Spiroplasma citri gen. and sp. n.: a mycoplasma-like organism associated with "stubborn" disease of citrus. Int. J. Syst. Bacteriol. 23:191-204.

36. Sambrook, J., Fritsch, E. F., and Maniatis, T. eds. 1989. Molecular Cloning: A Laboratory Manual. Cold Spring Harbor Laboratory, Cold Spring Harbor, NY.

37. Skroch, P., and Nienhuis, J. 1995. Impact of scoring error and reproducibility of RAPD data on RAPD based estimates of genetic distance. Theor. Appl. Genet. 91:1086-1091.

38. Townsend, R., Markham, P. G., Plaskitt, K. A., and Daniels, M. J. 1977. Isolation and characterization of a non-helical strain of Spiroplasma citri. J. Gen. Microbiol. 100:15-21.

39. Tully, J. G. 1983. Dark-field microscopy. Pages 35-37 in: Methods in Mycoplasmology. S. Razin and J. G. Tully, eds. Academic Press Inc., New York.

40. Tyler, K. D., Wang, G., Tyler, S. D., and Johnson, W. M. 1997. Factors affecting reliability and reproducibility of amplification-based DNA fingerprinting of representative bacterial pathogens. J. Clin. Microbiol. 35:339-346.

41. van Belkum, A., Scherer, S., van Alphen, L., and Verbrugh, H. 1998. Short-sequence DNA repeats in prokaryotic genomes. Microbiol. Mol. Biol. Rev. 62:275-293.

42. Wayadande, A. C., and Fletcher, J. 1995. 
Transmission of Spiroplasma citri lines and their ability to cross gut and salivary gland barriers within the leafhopper vector Circulifer tenellus. Phytopathology 85:1256-1259.

43. Ye, F., Laigret, F., Whitley, J. C., Citti, C., Finch, L. R., Carle, P., Renaudin, J., and Bové,
J. M. 1992. A physical and genetic map of the Spiroplasma citri genome. Nucleic Acids Res. 20:1559-1565.

44. Ye, F., Melcher, U., Rascoe, J. E., and Fletcher, J. 1996. Extensive chromosome aberrations in Spiroplasma citri strain BR3. Biochem. Genet.
34:269-286.

45. Yokomi, R. K., Mello, A. F. S., Saponari, M., and Fletcher, J. 2008. Polymerase chain reaction-based detection of Spiroplasma citri associated with citrus stubborn disease. Plant Dis. 92:253-260. 